\title{
SEXUAL PRECOCITY ASSOCIATED WITH THE CONCENTRATION OF PLASMA PROGESTERONE IN NELORE HEIFERS RAISED IN NORTHERN BRAZIL
}

\author{
Daniel Ribeiro Guimarães de Menezes ${ }^{1}$, Andrey Luiz Lopes Cordeiro', Rafael Augusto Satrapa ${ }^{1}$ \\ 1Universidade Federal do Acre (UFAC). Rodovia BR 364, Km 04 - Distrito Industrial, CEP: 69920-900, Rio Branco - AC, Brazil.
}

Autor para correspondência: Rafael Augusto Satrapa, rsatrapa@yahoo.com.br

\begin{abstract}
The objective of this study was to identify sexually precocious heifers by observing ovulation (presence of corpus luteum - $\mathrm{CL}$ ) and correlating it with the plasma progesterone concentration, as well as to verify the accuracy of the ultrasound examination (US) in this class of animals. The animals were kept in Brachiaria brizantha pastures in an extensive system with water and mineralized salt ad libitum. Nelore heifers $(n=50)$ with initial age and weight of 10 months old and $210 \mathrm{~kg}$, respectively, were used. Only 14\% (7/50; $p<0.05)$ of the heifers entered puberty at up to 12 months of age. Regarding the accuracy of the US in relation to the plasmatic concentration of P4 we verified that both the animals with and without CL presented concentrations of P4 inconsistent with the expected. The means of the plasmatic concentrations of P4 in pubertal heifers were superior $(p<0.05)$ in both second and third ultrasonographic exams $(1.30 \pm 0.14$ and $1.74 \pm 0.22 \mathrm{ng} / \mathrm{mL}$, respectively), when compared to the non-pubertal heifers $(0.53 \pm 0.08,0.89 \pm 0.04 \mathrm{ng} / \mathrm{mL}$, respectively). In conclusion, the herd presented low sexual precocity and the accuracy of the ultrasound examination in this class of animals was relatively low.
\end{abstract}

KEYWORDS: Bos indicus; Corpus luteum; Ovulation; Puberty; Ultrasonography.

\section{PRECOCIDADE SEXUAL ASSOCIADA À CONCENTRAÇÃO PLASMÁTICA DE PROGESTERONA EM NOVI- LHAS NELORE CRIADAS NO NORTE DO BRASIL}

RESUMO: Objetivou-se identificar, em uma microrregião do estado de Rondônia, novilhas sexualmente precoces através da observação da ovulação (presença de corpo lúteo - CL) e correlacioná-la com a concentração plasmática de progesterona, além de verificar a acurácia do exame ultrassonográfico ovariano (US) nesta classe de animais. Foram utilizadas 50 novilhas, Nelore, com idade inicial de 10 meses e $210 \mathrm{~kg}$ de peso, mantidas em pastagens de Brachiaria brizantha, em sistema extensivo. Somente $14 \%(7 / 50 ; p<0,05)$ das novilhas entraram na puberdade até os 12 meses de idade. No que diz respeito à acurácia do US em relação à concentração plasmática de P4, verificou-se que tantos os animais que apresentaram CL quanto aqueles com ausência de CL exibiram concentrações de P4 incompatíveis com o que se esperava. As médias das concentrações plasmáticas de P4 em novilhas púberes apresentaram níveis superiores $(p<0,05)$, tanto no segundo quanto no terceiro exames ultrassonográficos $(1,30 \pm 0,14$ e 1,74 $\pm 0,22 \mathrm{ng} / \mathrm{mL}$, respectivamente), quando comparadas às não púberes $(0,53 \pm 0,08$ $\mathrm{ng} / \mathrm{mL} ; 0,89 \pm 0,04 \mathrm{ng} / \mathrm{mL}$, respectivamente). Em conclusão, o rebanho apresentou baixa precocidade sexual e a acurácia do exame ultrassonográfico nesta classe de animais foi relativamente baixa.

PALAVRAS CHAVE: Bos indicus; Corpo lúteo; Ovulação; Puberdade; Ultrassonografia.

\section{INTRODUCTION}

The Brazilian Gross Domestic Product (GDP) dropped by $3.3 \%$ in 2016 when compared to 2015 , according to the Brazilian Institute of Geography and Statistics (IBGE, 2018). Among the sectors of the economy analyzed to calculate the GDP, only agriculture and livestock grew, with an increase of $1.8 \%$. Brazilian agribusiness had a share of $23 \%$ of the GPD in the country's economy in 2015, and livestock closed
2016 with a Gross Production Value (GPV) of R $\$ 527.9$ billion, of which cattle production reached $\mathrm{R} \$ 72$ billion (IBGE, 2016).

Brazilian livestock production has the largest commercial herd of beef cattle worldwide, with more than 218.23 million head, and the northern region presenting approximately 46 million of this total (IBGE, 2014), highlighting the country as the largest exporter of beef in the world (IBGE, 2016). Among the breeds in the 
country, Nelore presents the highest number of heads, approximately 90 million, representing $80 \%$ of the beef cattle herd (ACNB, 2006).

Despite presenting a large herd, low productivity and low reproductive efficiency prevent Brazilian cattle from showing its high economic potential, which is reflected by only $10 \%$ of the properties working with appropriate technology and the remaining $90 \%$ presenting an unsatisfactory technological level (Ipardes, 2002). Countless researches are developed for animal reproductive biotechnology when considering productive and reproductive improvements.

The primary objective of a farmstead is the production of $1 \mathrm{calf} / \mathrm{cow} / \mathrm{year}$, and the delay in production decreases the economic success of the activity. A large number of pre-pubescent heifers at the beginning of the breeding season is a hindrance for producers to start profiting from the activity. Heifers who breed earlier have a longer reproductive life than later ones. Thus, heifers that have their first calving near the age of two years, i.e., first breeding at 15 months, indicate maximum reproductive efficiency since they produce more calves during their lives (Lesmeister et al., 1973; Ferrel, 1982; Patterson et al., 1992).

The level of precocity in a herd can be measured by the age at puberty, which is one of the most essential parameters for the reproductive success of a herd. For heifers, puberty can be defined from the moment it presents the first estrus, allied with the first ovulation, which should occur from the $10^{\text {th }}$ to the $24^{\text {th }}$ month of age (Patterson et al., 1992; Pereira, 2000; Moraes et al., 2007), followed by the development of a functional $C L$ that can be confirmed by the US exam or plasmatic concentrations of P4 (Rodrigues et al., 2002).

In general, zebu heifers reach puberty when presenting $50-60 \%$ of their adult weight (Abeygunawardena et al., 1994). In this context, the estimated age at first ovulation in Bos indicus occurs on average at 25 months (Galina and Arthur, 1989; Mukasa-Mugerwa, 1989).

Many factors can influence the moment in which the first ovulation occurs, such as genetics, nutrition, management, season of the year, use of hormonal protocols, and the effect of the bull during biostimulation (Honaramooz et al., 1999; Pereira, 2000; Gasser et al., 2006; Silva Filho et al., 2007; Oliveira et al., 2009).
Sexual precocity is characterized by the early increase of luteinizing hormone (LH) pulses, the concentration of estradiol, the diameter of the dominant follicles, and the duration of the follicular waves in the pre-puberty period (Gasser et al., 2006a; Gasser et al., 2006b). According to Eler et al. (2002), a decrease in age at puberty from three to two years in Nellore animals would increase the economic return by $16 \%$. In Nellore heifers, the anticipation of the first calving to 30 months increases production by $45 \%$ (Teixeira, 1997).

Thus, the objective of the study was to identify sexually precocious heifers by observing their ovulation (presence of corpus luteum - CL) and correlating it with the concentration of plasmatic progesterone and verify the accuracy of the ovarian ultrasound exam (US) for this class of animal from a microregion in the state of Rondônia, Brazil

\section{MATERIAL AND METHODS \\ Experiment location and animals.}

Nelore heifers $(n=50)$ with an initial age of 10 months and weight $210 \mathrm{~kg}$ were kept in an extensive system located at the Fazenda Serra Bonita $\left(9^{\circ} 6^{\prime} 9^{\prime \prime} S\right.$ $64^{\circ} 5^{\prime} 45^{\prime \prime} \mathrm{W}$ ), in the municipality of Porto Velho, state of Rondonia, Brazil. The heifers were fed pasture (Brachiaria brizantha), with water and mineral salt (Supremax Methionine 65S) provided ad libitum. The animals were homogenously selected from a lot of 250 heifers considering their weight and age, and identified with numbered earrings. The experiment occurred between June and August 2016.

\section{Ultrasound Exams (US)}

Three ultrasound exams were performed on the ovaries (DP2200VET and $5.0 \mathrm{MHz}$ rectal transducer, Mindray) with an interval of approximately 20 days $(27 / 06,16 / 07 ; 06 / 08 / 2016)$ to identify probable ovulations (presence of $\mathrm{CL}$ ).

\section{Blood sampling for dosing the plasmatic progesterone (P4)}

Blood samples were collected by venipuncture of the coccygeal vein using vacutainer tubes containing heparin from all animals indicating $\mathrm{CL}$ on the ultrasound exam and from an equal number of animals without $\mathrm{CL}$ for comparison purposes. 
Immediately after the collection, the vacutainer tubes containing the blood samples were stored in a refrigerated thermal box. The samples were then centrifuged at $2500 \mathrm{G}$ for ten minutes and stored the plasmas obtained in $1 \mathrm{ml}$ microtubes in a freezer at $-20^{\circ} \mathrm{C}$ until the time for dosing the progesterone.

\section{Dosage of the plasmatic concentration of progesterone and animal weighing.}

The plasmatic concentrations of P4 were determined using chemiluminescence, according to standard laboratory methodology at the VETPAT (Laboratory of Clinical Veterinary Analysis, Campinas-SP).

The animals were weighed during the three months of experimentation using an electronic scale (Beckhauser idBECK 1.0), with the aid of a containment cattle chute.

\section{Statistical Analysis}

For the statistical analysis, the ovulation rates (presence or absence of $\mathrm{CL}$ ) were arranged into contingency tables and analyzed using the chi-square test at 5\% probability (Sampaio, 2002; Minitab for Mac program 2016).

The means of the plasmatic concentrations of progesterone were analyzed and compared using ANOVA (Minitab for Mac program, Copyright 2016, Minitab). The differences were considered significant when $p<0.05$.

\section{RESULTS}

The first US exam showed that none of the heifers had ovulated. The second US exam indicated the ovulation of 5 heifers $(10 \%)$, whereas, in the third and last US exam, only 3 heifers presented CL (6\%), one of which had ovulated in the previous exam. Thus, when analyzing the ovulation rates was observed that only $14 \%(7 / 50)$ of the heifers entered puberty in up to 12 months of age, which is significantly lower than the non-pubertal rates (86\%; Table 1).

Regarding the results of the accuracy of the ultrasonographic exams on the plasmatic concentration of P4, was observed that the animals did not present P4 concentration consistent with the presence or absence of $\mathrm{CL}$ (Tables 2, 3, and 4). Thus, these results indicate that there was a low accuracy of the ultrasound exams $(p>0.05)$.

Table 1. Percentage and absolute number of animals with and without corpus luteum in the tree ultrasound exams. Rondônia, Brazil 2016. Distinct letters in columns, $p<0.05$. One of the animals had already presented CL in the US exam of 08/16/2016.

\begin{tabular}{ccccc}
\hline Corpus luteum & $\mathbf{0 6 / 2 7 / 2 0 1 6}$ & $\mathbf{0 7 / 1 6 / 2 0 1 6}$ & $\mathbf{0 8 / 0 6 / 2 0 1 6}$ & TOTAL \\
\hline+ & $0 \%(0 / 50)^{\mathrm{a}}$ & $10 \%(5 / 50)^{\mathrm{a}}$ & $6 \%\left(3^{*} / 50\right)^{\mathrm{a}}$ & $14 \%(7 / 50)^{\mathrm{a}}$ \\
- & $100 \%(50 / 50)^{\mathrm{b}}$ & $90 \%(45 / 50)^{\mathrm{b}}$ & $94 \%(47 / 50)^{\mathrm{b}}$ & $86 \%(43 / 50)^{\mathrm{b}}$ \\
\hline
\end{tabular}

Table 2. Percentage and absolute number of animals with a plasmatic concentration of progesterone ([ ] P4) superior or inferior to $1.0 \mathrm{ng} / \mathrm{mL}$. Rondônia, Brazil 2016.

Distinct letters in columns, $p<0.05$.

\begin{tabular}{ccccc}
\hline [ ] P4 (ng/mL) & $\mathbf{0 7 / 1 6 / 2 0 1 6}$ & $\mathbf{0 8 / 0 6 / 2 0 1 6}$ & Total & HERD TOTAL \\
\hline$>1.0$ & $30 \%(3 / 10)^{\mathrm{a}}$ & $67 \%(4 / 6)^{\mathrm{a}}$ & $44 \%(7 / 16)^{\mathrm{a}}$ & $14 \%(7 / 50)^{\mathrm{a}}$ \\
$<1.0$ & $70 \%(7 / 10)^{\mathrm{a}}$ & $33 \%(2 / 6)^{\mathrm{a}}$ & $56 \%(9 / 16)^{\mathrm{a}}$ & $86 \%(43 / 50)^{\mathrm{b}}$ \\
\hline
\end{tabular}

Table 3. Percentage of animals with (CL+) or without corpus luteum (CL-) detected in the US exam compared with the plasmatic concentration of progesterone ([ ] P4) superior or inferior to $1.0 \mathrm{ng} / \mathrm{mL}$. Rondônia, Brazil 2016. Distinct letters in columns, $p<0.05$.

\begin{tabular}{cccc}
\hline [ ] P4 (ng/mL) & CL + & CL - & HERD TOTAL \\
\hline$>1.0$ & $31.2 \%(5 / 16)^{\mathrm{a}}$ & $12.5 \%(2 / 16)^{\mathrm{a}}$ & $14 \%(7 / 50)^{\mathrm{a}}$ \\
$<1.0$ & $18.8 \%(3 / 16)^{\mathrm{a}}$ & $37.5 \%(6 / 16)^{\mathrm{a}}$ & $86 \%(43 / 50)^{\mathrm{b}}$ \\
\hline
\end{tabular}


Table 4. Plasmatic concentration of progesterone (mean \pm SE) of positive and negative animals according to the presence or absence of corpus luteum. Rondônia, Brazil 2016.

\begin{tabular}{ccccc}
\hline & $07 / 16 / 2016$ & \multicolumn{2}{c}{$08 / 06 / 2016$} \\
$C L+$ & & $C l-$ & $C l+$ & $C l-$ \\
$0.93 \pm 0.47$ & & $0.59 \pm 0.35$ & $2.08 \pm 0.16$ & $0.94 \pm 0.10$ \\
\hline
\end{tabular}

When analyzing the mean plasmatic and third ultrasonography exams $(1.30 \pm 0.14$ and concentrations of progesterone, was observed that $1.74 \pm 0.22 \mathrm{ng} / \mathrm{mL}$, respectively), when compared to the heifers considered pubescent presented higher non-pubertal heifers $(0.53 \pm 0.08$ and $0.89 \pm 0.04 \mathrm{ng} /$ concentrations of P4 $(p<0.05)$, in both the second $\mathrm{mL}$, respectively) (Fig. 1).

Figure 1. Plasmatic concentrations of progesterone (mean \pm SE) of the 16 Nellore heifers. Distinct letters, $p<0.05$.

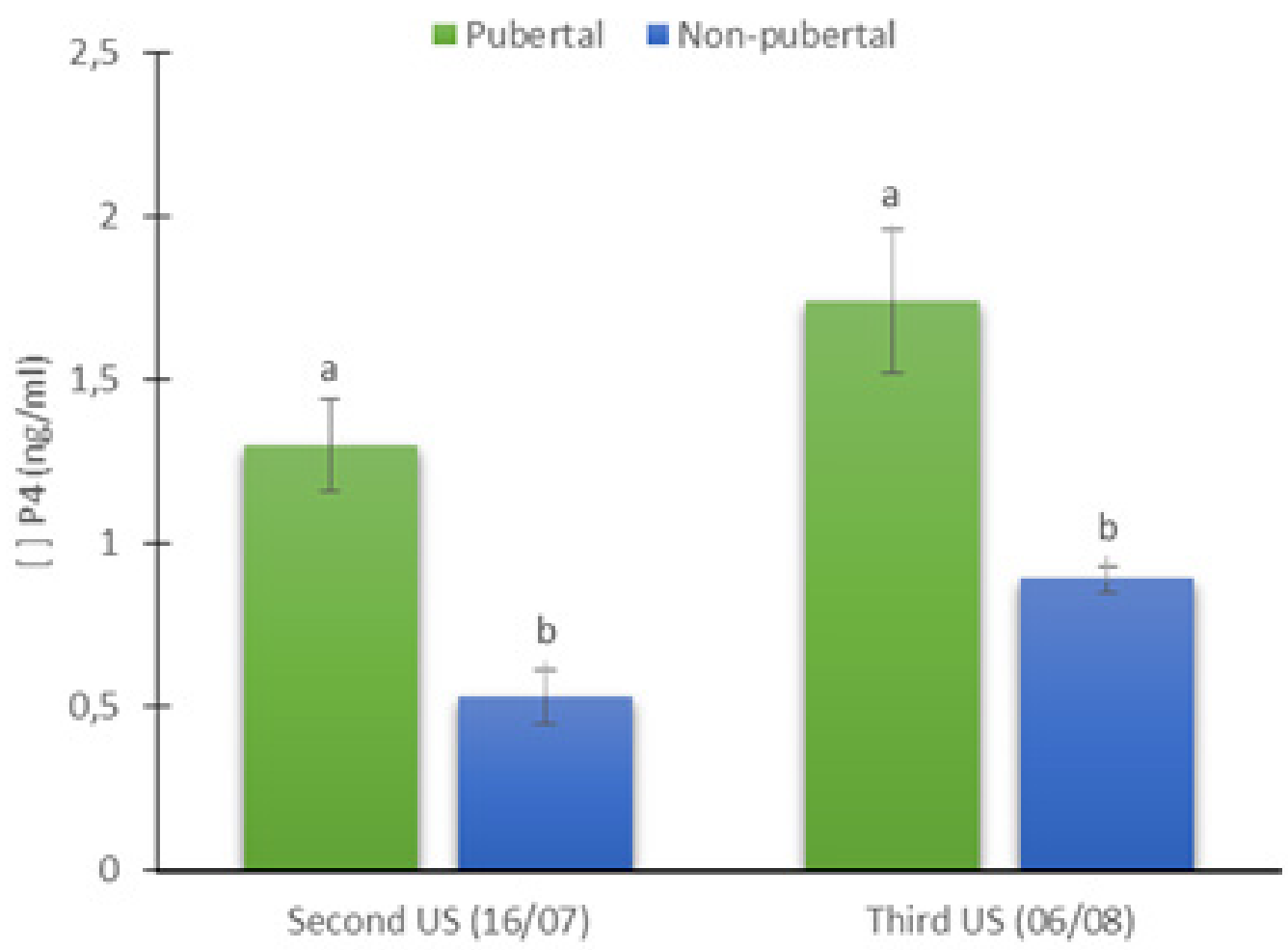

\section{DISCUSSION}

These results confirm those obtained by Souza (2003) in 283 animals, who observed that the pregnancies of the first heifers were diagnosed only at 14 months, with a general average for the entire herd at 26 months. Furthermore, Monteiro (2011) observed that the first heifers showed puberty only after 18 months when analyzing the puberty in Nelore animal. Conversely, in an experiment using Japanese Black (JB) female calves, the first heifers reached puberty at 8 months of age, acknowledging great genetic differences in precocity rates between cattle lineages (El-Sheikh Ali et al., 2017).

According to Owens et al. (1993), the age at which the heifers reach puberty is mainly related to breed and weight. Animals of zebuine breeds generally reach puberty with $55-65 \%$ of their adult weight at the beginning of the breeding season, around $300-330 \mathrm{~kg}$ (Schillo et al., 1992). These observations corroborate the results of the present study, where the mean weight of heifers remained at $226 \mathrm{~kg}$, demonstrating a negative energy balance which reflected in a low number of heifers that reached puberty up to 12 months (Table 5). 
Table 5. Plasmatic concentration of progesterone (mean \pm SE) of positive and negative animals according to the presence or absence of corpus luteum. Rondônia, Brazil 2016.

\begin{tabular}{ccccc}
\hline & $06 / 27 / 2016$ & $07 / 16 / 2016$ & $08 / 06 / 2016$ & General Mean \\
\hline Mean weight $(\mathrm{Kg})$ & 211 & 243 & 226 & 225 \\
\hline
\end{tabular}

Schillo et al. (1992) state that nutritional characteristics are inversely related to age at puberty, that is, the number of days needed for the animal to become pubescent decreases as the nutritional level increases. Following this reasoning, the nutritional factor has a vital role in the expression of the potential of precocious puberty. However, more important than the weight is the fact that the animal is gaining or losing weight, which interferes in the secretion of gonadotrophins and follicular development (Nogueira, 2006). Although the relationship between nutritional factors and endocrine mechanisms has not been fully elucidated, it is known that the nutrition can influence the age at puberty and possibly interfere with the onset of hormone production, and secretion and inhibition of gonadotrophins (Segui et al., 2002; OliveirA Filho, 2008).

Neves et al. (2009) observed that the increase in the availability of forage provides an increase in the probability of estrus in heifers, making this management possible as an alternative to improve the reproductive indexes. According Ferraz et al. (2018), with adequate nutrition and selection Nelore heifers can reach puberty at only 18 months, moreover the authors stated that achieving ovulation before this time was a viable target. In the same experiment more than half of heifers achieved puberty before the age of 18 months, the group with better results was selected from sires with precocious age at first calving and the heifers treated with high quality feed, as a result the treatment anticipated puberty in $62 \%$ of the heifers. In this sense, the low number of pubescent heifers in the present study may also be related to low food availability due to severe drought in the region between June and September 2016.

Another factor that justifies the low number of sexually precocious animals in this study was the absence of the proximity of a male to these heifers, which would probably anticipate puberty. According to Costa (2008), the "bull effect" translates into a sensorial stimulus (for example, pheromones) on the hypothalamic-pituitary axis of the female, acting on the secretion of gonadotrophins with the consequent manifestation of puberty. The vomeronasal organ is recognized as a pheromone-detecting organ, pheromones being substances emitted by an organism through the urine, feces, saliva, and sweat glands (Emerick et al., 2009).

Spire (1997) verified that heifers submitted to the presence of the bull reached puberty at an earlier age and with lower body weight, but a minimum time of three months was necessary. Regarding sexual precocity, Wehrman et al. (1996) and Ormazabal et al. (1997) did not observe positive effects with the exposure of heifers to the bull.

Concerning the accuracy of the ultrasonographic exams, those findings are probably due to the inherent difficulty of the ultrasonography exam in heifers of 10 to 12 months, especially concerning the mobility of the probe considering the anatomical size of the rectum. Moreover, the size of the ovarian structures in this class of animal makes difficult the formation of images of the reproductive tract, leading to the divergence in the results between the concentration of P4 and the presence or absence of $\mathrm{CL}$, thus influencing the accuracy of the results.

In the present study the heifers considered pubescent presented higher concentrations of P4 when compared to non-pubertal heifers. These results are in line with those obtained by Monteiro (2011), who observed a significantly higher progesterone concentration in Nelore heifers that reached puberty $(5.9 \pm 0.37 \mathrm{ng} / \mathrm{mL})$ when compared to nonpubertal heifers $(0.53 \pm 0.38 \mathrm{ng} / \mathrm{ml})$. Ali et al. (2017), reported a concentration around $4.5 \mathrm{ng} / \mathrm{ml}$ at the onset of puberty in Japanese Black heifers, these values were similar to those presented by Monteiro (2011) and greater than those found by the present study.

This discrepancy between the P4 levels in the animals considered pubescent in the present experiment $(1.30 \pm 0.14$ and $1.74 \pm 0.22 \mathrm{ng} / \mathrm{mL})$ and those found by Monteiro (2011) $(5.9 \pm 0.37 \mathrm{ng} / \mathrm{mL})$ was probably due to the difference in age at puberty, which in the experiment of Monteiro was higher (18 to 20 months). Another factor that may justify this difference is 
the size of the corpus luteum, which are larger in heifers with more advanced ages and probably produce a more significant amount of P4 when compared to more precocious heifers. Furthermore, the life span of the $\mathrm{CL}$ interferes with the concentration of P4 that, according to Mucciolo e Barbeiro (1983), reach their maximum values only in the second week after ovulation.

According to the functionality of $\mathrm{CL}$ between the growth, maintenance, and regression phases, the progesterone may present variations in its secretion and plasmatic concentration during the estrous cycle (Borges et al., 2003). According to Adeyemo and Heath (1980), in adult Zebu cattle, concentrations below $1 \mathrm{ng} /$ $\mathrm{ml}$ are observed during the estrous, occurring at up to the $10^{\text {th }}$ day and reaching a maximum of $4.5 \mathrm{ng} / \mathrm{ml}$.

Thus, the results of the present experiment demonstrated that essential factors such as age, weight, energetic balance, and the presence of the bull directly influence the sexual precocity of heifers. In this context, the low number of precocious heifers observed can be attributed to the age of the animals, the negative energy balance, and the absence of the bull near the heifers. In turn, the accuracy of the ultrasound results was influenced by the higher difficulty of using this technique in heifers when compared to cows, mainly due to the difference in the anatomical size of the rectum and ovarian structures, thus resulting in the low accuracy of the ultrasound exam in this experiment.

\section{ACKNOWLEDGMENTS}

This work was supported by the CAPES program of Ministry of Education in Brazil through scholarship.

\section{REFERENCES}

Abeygunawardena, H.; Abayawansa W. D.; Ratnayake, D.; Jayatilaka, M. W. A. P. Zebu cattle farming in Sri Lanka: production systems and reproductive characteristics. In: Research on Animal Reproduction and Disease Diagnosis in Asia Through the Application of Immunoassay Techniques, Vienna. Annals... Austria. Vienna: IAEA, 1994. pp .226, 1994.

ACNB - Associação dos Criadores de Nelore do Brasil, 2006. Available in: http://www.nelore.org.br/. Acessed in: 03/01/2017.
Adeyemo, O.; Heath, E. Plasma progesterone concentration in Bos taurus and Bos indicus heifers. Theriogenology, 1980, 14, 411-420.

Borges, A. M.; Torres, C. A. A.; Ruas, J. R. M.; Ribeiro, V.; Rocha Júnior, G. R. D. C. Desenvolvimento luteal e concentrações plasmáticas de progesterona em vacas das raças Gir e Nelore. Revista Brasileira de Zootecnia, 2003, 32, 276-283.

Costa, A. N. L. Sincronização do estro e ovulação em novilhas girolandas: comparação entre dois protocolos hormonais, "CIDR-B" E "OVSYNCH". Revista Ciência Agronômica, 2008, 39, 137-141.

El-Sheikh Ali, H.; Kitahara, G; Takahashi, T., Mido, S.; Sadawy, M.; Kobayashi, I.; Hemmi, K.; Osawa, T. Plasma Anti-Müllerian hormone profile in heifers from birth through puberty and relationship with puberty onset. Biology of Reproduction, 2017, 97, 153-161.

Emerick, L. L.; Dias, J. C.; Gonçalves, P. E.; Martins, J. A.; Leite, T. G.; Andrade, V. J.; Vale Filho, V. R. Aspectos relevantes sobre a puberdade em fêmeas. Revista Brasileira de Reprodução Animal, 2009, 33, 11-19.

Ferraz, M. V. C.; Pires, A. V.; Santos, M. H.; Silva, R. G.; Oliveira, G. B.; Polizel, D. M.; Biehl, M.V.; Sartori, R.; Nogueira, G. P. A combination of nutrition and genetics is able to reduce age at puberty in Nelore heifers to below 18 months. Animal, 2018, 12, 569-574.

Ferrell, C. L. Effects of post-weaning rate of gain on onset of puberty and productive performance of heifers of different breeds. Journal of Animal Science, 1982, $55,1272-1283$.

Galina, C. S.; Arthur, G. H. Review of cattle reproduction in the tropics. Part 1. Puberty and age at first calving. Archiv fur Tierzucht, 1989, 57, 583-590.

Gasser, C. L.; Bridges, G. A.; Mussard, M. L.; Grum, D. E.; Kinder, J. E.; Day, M. L. Induction of precocious puberty in heifers III: Hastened reduction of estradiol negative feedback on secretion of luteinizing hormone. Journal of Animal Science, 2006, 84, 2050-2056.

Honaramooz, A.; Chandolia, R. K.; Beard, A. P.; Rawlings, N. C. Effects of season of birth on the 
prepubertal pattern of gonadotropin secretion and age at puberty in beef heifers. Theriogenology, 1999, 52, 67-79.

IBGE - Instituto Brasileiro de Geografia e Estatística, 2016. Available in: http://www.ibge.gov.br. Acessed in: 27/03/2017.

IBGE - Instituto Brasileiro de Geografia e Estatística, 2018. Instituto Brasileiro de Geografia e Estatística. Available in: http://www.ibge.gov.br. Acessed in: 01/02/2019.

IPARDES - Instituto Paranaense de Desenvolvimento Econômico Social, 2002. Grupo de Estudos de Políticas Agroindustriais. Análise da competitividade da cadeia agroindustrial da carne bovina no estado do Paraná. Available in: http://www.ipardes.gov.br. Acessed in: 14/11/2017.

Lesmeister, J. L.; Burfening, P. J.; Blackwell, R. L. Date of first calving in beef cows and subsequent calf production. Journal of Animal Science, 1973, 36, 1-6.

Monteiro, F. M. Puberdade em novilhas Nelore provenientes de duas linhas de seleção para peso. Jaboticabal: Faculdade de Ciências Agrárias e Veterinárias - Unesp, 2011. Thesis.

Moraes, J.; Jaume, C.; Souza, C. Manejo reprodutivo da vaca de corte. Revista Brasileira de Reprodução Animal, 2007, 31, 160-166.

Mucciolo, R. G.; Barbeiro, J. C. Níveis de progesterona no plasma sanguíneo durante o ciclo estral e gestação de vacas Nelore (Bos taurus indicus). Revista Brasileira de Reprodução Animal, 1983, 7, 11-21.

Mukasa-Mugerwa, E. A. Review of Reproductive Performance of Female Bos indicus (Zebu) Cattle. 1989. Thesis - International Livestock Centre for Africa, Nairobi, Kenya.

Neves, F. P.; Carvalho, P. C. D. F.; Nabinger, C.; Jacques, A. V. A.; Carassai, I. J.; Tentardini, F. R. Estratégias de manejo da oferta de forragem para recria de novilhas em pastagem natural. Revista Brasileira de Zootecnia, 2009, 38, 1532-1542.
Nogueira, G. P. Puberdade e maturidade sexual de novilhas bos indicus. In: II Simpósio Internacional de Reprodução Animal Aplicada, Londrina. Annals... Londrina, PR: UNESP, 2006, pp .112, 2006.

Oliveira Filho, B. D. Interações entre nutrição e reprodução em bovinos de corte. In: $35^{\text {th }}$ Encontro Regional de Saúde Pública em Medicina Veterinária, Guarapari. Annals... Guarapari, ES, 2008, pp .16, 2008.

Oliveira, C. M. G.; Oliveira Filho, B. D.; Gambarini, M. L.; Viu, M. A. O.; Lopes, D. T.; Sousa, A. P. F. Effects of biostimulation and nutritional supplementation on pubertal age and pregnancy rates of Nelore heifers (Bos indicus) in a tropical environment. Animal Reproduction. Science, 2009, 113, 38-43.

Ormazabal, J. J.; Osoro, K.; Martínez, A. Efecto de los niveles de crecimiento y la presencia del toro em la edad a la pubertad de las novillas de raza Asturiana de los Vales. Investigación Agraria: Producción y Aanidad Animal, 1996, 11, 201-213.

Owens, F. N.; Dubeski, P.; Hanson, C. F. Factors that Alter the Growth and Development of Ruminants. Journal of Animal Science, 1993, 71, 3138-3150.

Patterson, D. J.; Perry, R. C.; Kiracofe, G. H.; Bellows, R. A.; Staigmiller, R. B.; Corah L. R. Management considerations in heifer development and puberty. Journal of Animal Science, 1992, 70, 4018 - 4035.

Pereira, J. C. C. Contribuição genética do Zebu na pecuária bovina do Brasil. Revista Informe Agropecuário, 2000, 21, 30-38.

Rodrigues, H. D.; Kinder, J. E.; Fitzpatrick, L. A. Estradiol regulation of luteinizing hormone secretion in heifers of two breed types that reach puberty at different ages. Biology of Reproduction, 2002, 66, 603-609.

Sampaio, I. B. M. (Eds). Estatística aplicada à experimentação animal. Belo Horizonte, MG, Brazil: Fundação de Ensino e Pesquisa em Medicina Veterinária e Zootecnia, 2002, 221p.

Schillo, K. K.; Hall, J. B.; Hileman, S. M. Effects of nutrition and season on the onset of puberty in the beef heifer. Journal of Animal Science, 1992, 70, 3994-4005. 
Segui, M. S.; Weiss, R. R.; Cunha, A. P.; Zoller, R. precocidade e musculosidade em fêmeas da raça Indução ao estro em bovinos de corte. Archives of nelore. 2003. Thesis, - UNESP, Botucatu, 2003.

Veterinary Science, 2002, 7, 173-178.

Spire, M. F. Managing replacement heifers from weaning Silva Filho, A. H. S.; Araújo, A. A.; Paula, A.; Rodrigues, $\quad$ to breeding. Veterinary Medicine, 1997, 92, 182-192. R. Indução da puberdade em novilhas com 0 uso da hormonioterapia. Ciência Animal, 2007, 17, 83-89.

Wehrman, M. E.; Kojima, F. N.; Sanchez, T.; Mariscal, D. V.; Kinder, J. E. Incidence of precocious puberty in Souza, J. F. Predição da precocidade sexual, na pré e developing beef heifers. Journal of Animal Science, puberdade, através de escores visuais de conformação, 1996, 74, 2462-2467. 